Eva Maria Luef*

\title{
Development of voice onset time in an ongoing phonetic differentiation in Austrian German plosives: Reversing a near-merger
}

https://doi.org/10.1515/zfs-2019-2006

Received January 17, 2019; accepted August 8, 2019; published online February 7, 2020

Abstract: Sound change in the form of plosive mergers has been reported for a variety of languages and is the result of a reduction of phonetic distance between two (or more) sounds. The present study is concerned with the opposite development of phonetic differentiation in plosives (akin to a phonetic split), a less commonly reported phenomenon that is taking place in Austrian German at the moment. A previously small (or null) phonetic distinction between fortis and lenis plosives - a presumed near-merger - is gradually developing into a clear phonetic contrast in younger speakers. In the present study, voice onset time of word-initial plosives was measured in two generations of Austrian speakers (born in the middle and at the end of the 20th century), yielding an ongoing phonetic differentiation where the voice onset time of lenis consonants is shortened while, at the same time, that of fortis consonants is lengthened. These results present an insight into the recent diachronic development of Austrian German and the changes in plosive production that are currently taking place.

Keywords: Austrian German, linguistic change, phonetic split, near-merger, plosive

\section{Introduction}

Different processes underlie sound change, depending on the exact selective pressures that are at work in a particular language at a certain time, and two prominent phonological mechanisms, namely merging and splitting of sounds are central concepts in the study of sound change (Labov 1994). Mergers are instances where distinctive features between sounds disappear, resulting in two (or more) phonemes approximating the same acoustical realization (Hickey 2004).

*Corresponding author: Eva Maria Luef, College of Education, Seoul National University, Gwanak-gu, 1 Gwanak-ro, 08826 Seoul, Republic of Korea; and Faculty of Arts, Department of English and ELT Methodology, Charles University Prague, nám. Jana Palacha 2, 116 38, Prague 1, Czech Republic, e-mail: eluef@gl-sec.com 
There are cases of near-mergers, i. e. where an auditory difference is retained even though articulation has merged, and it is possible that phonemic (or phonetic) contrasts are suspended for some period (Labov 1987). Splits, on the other hand, are representations of increases in phonetic discriminability and describe the process of one sound starting to develop two (or more) acoustically distinct variants (Piercy 2011; Smith 2007). In a more general sense, an increase in phonetic distance can be seen as a split, and the present paper will apply the term "split" in such a way. Research has shown that certain phonemes seem to be more prone to linguistic variation (Wedel et al. 2013), and among the consonants, plosives feature prominently in the literature on sound change (e.g., Coetzee et al. 2018; Kang 2014; Kanwal and Ritchart 2015; Kuang and Oh 2011; Martin et al. 2016).

A variety of socio-pragmatic ("external") and structural-linguistic ("internal”) processes can lead to mergers or splits (Hickey 2000, 2012). Among the ones dependent on social factors, perceptual prominence (so-called "salience", MacLeod 2012), accommodation toward a higher prestige variant or dissociation from a stigmatized variant (Milroy and Milroy 1999; Sloos 2018), and language contact situations (Winford 2005) are listed as particularly influential motivators. Once contrasts have been merged, theory predicts that they cannot be reinstated by phonological/phonetic means (Labov 1994). From a sociolinguistic point of view, a group of speakers may try to reverse a merger, however, it is assumed that a complete reversal can never be fully achieved. Reported cases of such reversals likely involved near-mergers rather than complete mergers (Labov 1994). The processes underlying a recovery of a near-merger can provide valuable hints at mechanisms responsible for reversing sociophonetic developments. The present study will offer evidence for such an ongoing trend in Austrian German.

A central acoustical feature of plosive consonants is voice onset time (VOT), the time measured from the burst of the closure to the start of the vibration of the vocal cords (Lisker and Abramson 1964). Three general phonetic categories of VOT are distinguished: (1) negative/zero VOT or voicing, (2) short positive VOT or short lag (under $40 \mathrm{msec}$ ), and (3) long positive VOT or long lag/aspiration (over $40 \mathrm{msec}$ ). It has been claimed that German is not a voice-utilizing language (Jessen 1998; Jessen and Ringen 2002; Petrova et al. 2006) and therefore occurrences of negative (or zero) VOT are rare (Jessen 1998; Kohler 1977; however see Hamann and Seinhorst 2016, for different findings), meaning that plosives are typically pronounced with short or long positive VOT. In Standard Austrian German (SAG, which is the focus of the present study), neither voice nor aspiration are characteristic features (Moosmüller 1987; Siebs 1969), leading to pronunciation patterns of plosives that are characterized by relatively short lags. Dialects of Austrian German have neutralized some fortis-lenis contrasts in word-initial 
position (at least in bilabial plosives, Hildenbrandt et al. 2013; Neubarth et al. 2008), however Standard Austrian German retains the contrast. The linguistic situation in Bavarian-speaking Austria can be described as a dialect-standard continuum (as opposed to Alemannic Western Austria, which can be seen as diglossic), with a versatile range of intermediate language forms which are not clearly characterized as dialect or Standard German (Ender and Kaiser 2011). Linguistic variety in Austria is highly dependent on social and pragmatic factors (Ammon 2003).

VOT can be used as a defining feature for the distinction of fortis and lenis (or often referred to as tense/lax) pronunciation of plosives, however there has been a controversy over what acoustical reality is entailed in the two concepts and whether fortition and lenition are dependent on acoustical parameters such as voice, aspiration, glottal aperture, or duration of articulatory stricture (Hardcastle 1973; Kohler 1984; Ladefoged and Maddieson 1996; Lisker and Abramson 1964; Malécot 1970). It has been suggested that (German) fortis plosives become distinguished already during the closure phase where more extensive movements as well as greater peak and average velocities of the articulators become evident (Kohler 1984). During the release phase of a plosive, glottal activity (voicing, aspiration) starts and further contributes to the distinction between the fortis-lenis opposition pairs (Kohler 1984). The majority of research classifies the fortis-lenis pairs of German plosives in word-initial position (i. e., b-p, d-t, g-k) as [ \pm spread glottis] and [ \pm aspiration] (Beckmann et al. 2013; Honeybone 2005; Iverson and Salmons 1999), and both concepts can be (indirectly) documented via VOT. In acoustic terms, spreading movement on the glottis (i. e., glottal opening) is reflected in the duration of aspiration in plosives. From an articulatory standpoint, wide glottal opening represents an articulatory correlate that can be applied to obstruents more generally (Ridouane et al. 2006). In Austrian German, fortis-lenis plosive pairs are suggested to be distinguished by [ \pm spread glottis], with some evidence that a neutralization process in fortis-lenis distinction is ongoing in at least the bilabial plosives (Moosmüller and Ringen 2004).

The present study investigates the synchronic difference of VOT duration in word-initial plosives in Standard Austrian German speakers of two generations. The author observed that the speech of younger Austrians born at the end of the 20th century displays more phonetic distinction in fortis-lenis contrasts in word-initial plosives than that of older generations of Austrians who show more advanced neutralization in identical linguistic situations. Thus, it seems that younger Austrians are undergoing a sound change by increasing the phonetic distance between fortis and lenis VOT in all plosive types. The prediction for the present study was that fortis-lenis VOTs are neutralized to a higher degree in the 
older generation of speakers, possibly merged or at least near-merged, whereas younger speakers show decreased lenis VOT and increased fortis VOT. Based on previous literature, the effect is expected to be most pronounced in bilabial and alveolar plosives. In addition, two different elicitation modes of the experimental stimuli (i. e., picture naming, reading) were considered under the hypothesis that more phonetic reduction is present in picture naming tasks (Barry and Andreeva 2001). A greater effect of the split was thus expected in read speech. Furthermore, different elicitation modes for test stimuli have implications for the increased use of dialectal features in a language (Pröll and Kleiner 2016). The issue of dialect versus standard language is particularly important in the context of the present study, as each linguistic style is associated with different plosive pronunciation in Austria (Moosmüller 2011).

\section{Methods}

\subsection{Participants and procedures}

Comparative data were gathered from two generations of native Austrian speakers born in the middle (1950's and 60's) and end (1980's and 90's) of the 20th century. Speakers of both generations were recruited for participation in an apparent-time phonological experiment measuring voice onset time in word-initial plosives. Audio data and demographic information from the participants $(N=32)$, recruited in Upper Austria (region Braunau am Inn), were collected between February and October 2017. Fifteen women and seventeen men, aged between 22 and 70 years, with different educational backgrounds (i. e., highest education degrees obtained from primary, secondary or tertiary schools, see Moosmüller 2011; Moosmüller et al. 2015, for the role of education in Austrian pronunciation), were classified into two age classes (Generation 1 and 2) according to birth year (see Table 1). After being informed about the recording procedures and their rights as participants, consent was obtained from each participant before the recording started.

Literature suggests that speech patterns are highly resilient across the lifespan of an individual, and pronunciation of older people reflects the state of the language when it was acquired prior to the end of the critical period (Labov 1963, 1966). Even though there is some evidence that individuals may undergo sound changes as they age (Bóna 2014; Sankoff and Blondeau 2007) and biological age-related factors such as hormonal production may have an impact on acoustic features (Morris et al. 2009; Wadnerkar et al. 2006; Whiteside et al. 2004), 
Table 1: Demographic characteristics of the participants.

\begin{tabular}{|c|c|c|c|c|c|}
\hline \multirow[t]{2}{*}{ Characteristic } & \multirow[t]{2}{*}{$N$} & \multirow[t]{2}{*}{$\%$} & \multicolumn{3}{|c|}{ Highest education } \\
\hline & & & $\begin{array}{l}\text { Primary } \\
\text { education } \\
\text { (= } 9 \text { years } \\
\text { of school) }\end{array}$ & $\begin{array}{l}\text { Secondary } \\
\text { education } \\
\text { (= “Matura") }\end{array}$ & $\begin{array}{l}\text { Tertiary } \\
\text { education } \\
(=\text { college/ } \\
\text { university } \\
\text { degree })\end{array}$ \\
\hline $\begin{array}{l}\text { Generation } 1 \\
\text { (born in 1950's and 60's) }\end{array}$ & 16 & 50 & 5 & 2 & 9 \\
\hline Female & 8 & 25 & 1 & 2 & 4 \\
\hline Male & 8 & 25 & 4 & 0 & 5 \\
\hline $\begin{array}{l}\text { Generation } 2 \\
\text { (born in 1980's and 90's) }\end{array}$ & 16 & 50 & 4 & 3 & 9 \\
\hline Female & 7 & 21.9 & 3 & 2 & 2 \\
\hline Male & 9 & 28.1 & 1 & 1 & 7 \\
\hline
\end{tabular}

age-related phonological changes later in life may be comparable to interspeaker variability. Apparent time studies can therefore be reliable instruments for measuring sound change (Bailey 2002; Sankoff and Blondeau 2007; Tillery and Bailey 2003).

Participants were first asked to complete a survey detailing their linguistic habits (native language, dialect, excluding speech impediments etc.) and demographic information on their age, gender, and education. Next, they were given different reading and picture naming tasks in German that were intended to elicit a number of words $(N=53)$ containing different plosive types (see Supplementary Table SI). Due to differences in pronunciation patterns in picture naming and read speech (see Pröll and Kleiner 2016), a combination of both task types was chosen for the present experiments.

The reading tasks included reading sentences off a page and each speaker read the texts at a comfortable speed. In the picture naming tasks, participants had to describe objects in pictures and find plural forms of words they were given by the experimenter (see Table 2 for examples and Supplementary Table SI for full details on words and carrier sentences).

Each participant spoke each sentence once; no sentence had to be repeated due to pronunciation errors. In five instances, the participants did not use the intended words which led to exclusion of those words from the analyses (e. g., using Tasse 'cup' instead of Dose 'can'). The relevant plosives that were elicited and subsequently measured all occurred in word-initial accented positions, either in sub- 
Table 2: Example sentences from the reading task.

\begin{tabular}{ll}
\hline Plosive in question & Example sentences (target lexemes in bold) \\
\hline B & $\begin{array}{l}\text { Wir backen zu Weihnachten immer Kipferl./ Die Bären in Kanada können } \\
\text { gefährlich sein. }\end{array}$ \\
P & $\begin{array}{l}\text { Die Pest hat sehr viele Menschen in Europa getötet./ Machen wir eine } \\
\text { Pause. }\end{array}$ \\
D & $\begin{array}{l}\text { Die deutschen Dachse lassen sich in zwei große Gattungen } \\
\text { unterteilen./ Das Wasser schwappt über die Deiche. }\end{array}$ \\
T & $\begin{array}{l}\text { Die Tage werden länger und die Nächte kürzer./ Der Tee schmeckt } \\
\text { irgendwie minzig. }\end{array}$ \\
G & $\begin{array}{l}\text { Die Gerte ist für die Pferde-Erziehung unerlässlich./ Wir gehen ins } \\
\text { Fitnessstudio. }\end{array}$ \\
K & Es gibt Boote mit zwei Kielen./ Kleine Kinder lieben Märchen. \\
\hline
\end{tabular}

ject position (54.7\%) or object position (45.3\%). The relevant words could occur at the start of the sentences (e. g., Peter wohnt in Sebenstein 'Peter lives in Sebenstein'), following words that end in vowels (e. g., Die Bestnote war ein Gut 'The best grade was a B'), or following nasals (e. g., Er trat gegen den Tank 'He kicked against the fuel tank'). Words were chosen so that word stress was on the vowels immediately succeeding the plosives. Cases of deviant pronunciation (e. g., deaccentuated pronunciation of the target words) were excluded from the analysis. With filler sentences, the purpose of the study was concealed. Sentences containing stimulus words with the same plosive (bilabial, alveolar, velar) were spaced apart by a minimum of four sentences. The words and sentences were semantically unrelated. Some of the words were fortis-lenis minimal pairs (Dank - Tank 'thanks - fuel tank').

Speakers were advised to speak Standard Austrian German and not use dialect. As mentioned earlier, in Austrian dialects a fortis-lenis merger in plosives has been reported. That speakers may alter their pronunciation in formal laboratory settings (i. e., hyper- or hypo-articulation) is a well-recognized problem in experimental linguistics and can specifically affect voice onset time of target words (Nelson and Wedel 2017). In fact, older speakers may hyperarticulate more due to a slower speaking rate.

During the speech tasks, the participants were recorded with a ZoomH4n digital audio recorder to which a Sennheiser microphone (ME67) was attached. Speech was sampled at $44.1 \mathrm{kHz}$ with a 16-bit depth and subsequently saved and stored as .wav files. 


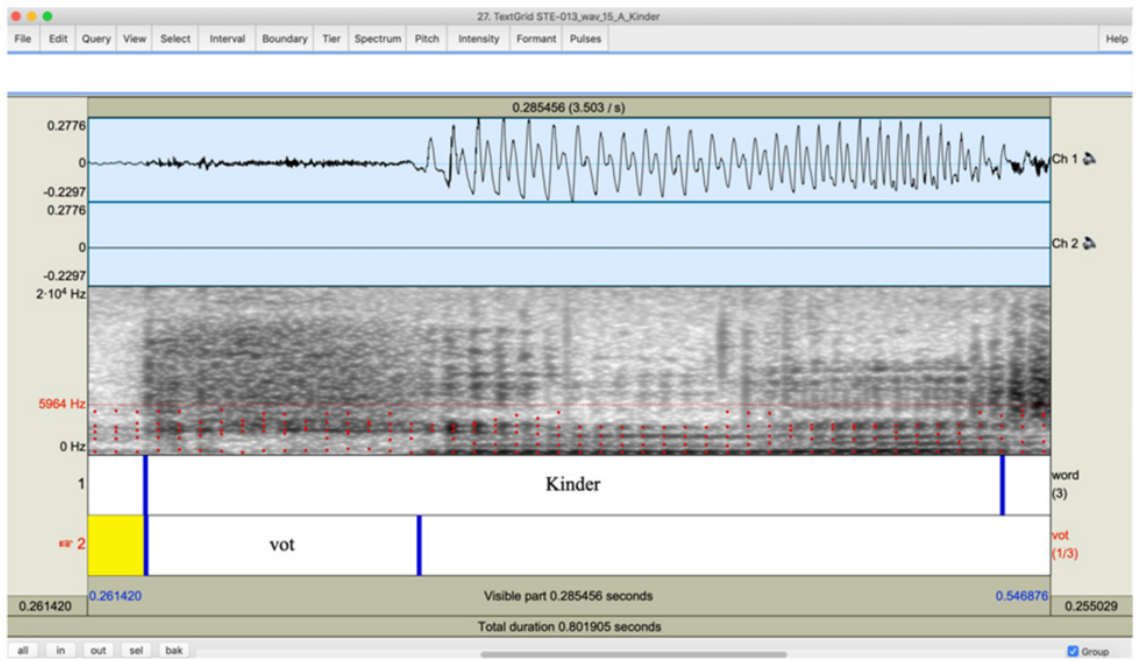

Figure 1a: Example of an annotation in Praat.

\subsection{Data analysis}

From the audio stream, all relevant words were cut manually and saved as .wav files. Praat (Boersma and Weenink 2007) was used to annotate the overall word duration and VOT of the initial plosives, each on a different annotation tier (see Figure 1a and 1b). VOT measurements were taken from the burst of the stop to the onset of glottal pulsing (see Abramson and Whalen 2017), and the proportions of VOT in relation to specific word durations were calculated (in order to control for differences in speech tempo). The following formula was used:

$$
\text { VOT proportion }=\frac{(\text { absolute duration of VOT of specific word } * 100)}{\text { absolute duration of specific word }}
$$

For instance, the duration of Kopf 'head' by speaker 1 was 0.405 seconds, the absolute duration of VOT was $0.066 \mathrm{sec}$, resulting in a VOT proportion of $16.3 \%$. Approximately $5 \%(N=97)$ of all files were coded for accuracy by a second coder and percentage ratios, Pearsons's $r$ (i. e., Pearson product-moment correlation coefficient), and intra-class correlation coefficients (ICCs) were calculated as measures of inter-rater reliability. VOT durations were formatted to two decimals and multiplied by 1000. Agreement of both coders on VOT duration annotations was $78 \%$ (Pearson's $r=0.98$ ), the intraclass correlation coefficient (ICC) equalled 0.97, which means that the agreement was very good (Liu et al. 2016). Scripts were then 


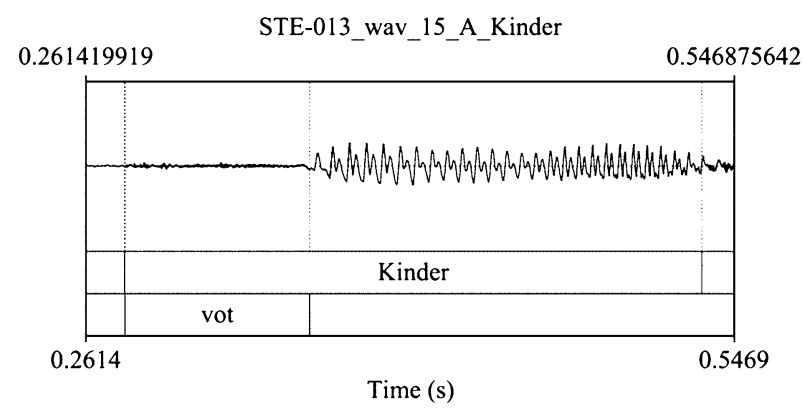

Figure 1b: Waveform including VOT annotation in Praat.

Table 3: Comparison of merge indices across Austrian German (present study), (North and Middle) Standard German, and American English.

\begin{tabular}{lrrr}
\hline & Bilabial & Alveolar & Velar \\
\hline Present study: $<40$ & 11.5 & 13.3 & 24.9 \\
Present study: $>50$ & 72.7 & 25.7 & 53.6 \\
North and Middle Standard German (Jessen 1998) & 9.3 & 23.4 & 33.3 \\
American English (Lisker and Abramson 1964) & 1.7 & 7.1 & 26.3 \\
\hline
\end{tabular}

used to extract the duration (in seconds) of the words and the voice onset time of the initial plosives from the annotated segments.

\subsubsection{VOT Merge Index}

An index that represents the degree of neutralization (merger) of VOT durations between fortis and lenis plosive pairs was developed by calculating the percentage of lenis in relation to fortis VOT duration ( $\left.{ }^{\star} 100\right)$. For instance, a merge index of 20.17 would indicates that the VOT of the lenis consonant comprises 20.17 percentage points of the VOT of the fortis consonant of the same plosive type (bilabial, alveolar, velar). A merge index of 100 indicates a complete merger, with lenis and fortis having identical VOT durations. Merge indices ranged from 0 to 153.9, the latter indicating that lenis VOTs were longer than fortis VOTs. These occurred exclusively in the bilabial plosives of speakers over 50 years (of variable educational backgrounds). To enable comparison, merge indices for North and Middle German and American English were calculated based on previous literature (Jessen 1998; Lisker and Abramson 1964) and included in Table 3. 
Table 3 shows that across the three compared languages (Austrian German $<40$, North and Middle Standard German, American English), the overlap in VOT durations between fortis and lenis plosive pairs is relatively low in bilabials and gets higher in alveolar and in particular in velar plosives. The Austrian sample of participants over 50 years shows very high merge indices in bilabials and velars and the lowest merge index in alveolar plosives.

\subsubsection{Statistical methods}

To examine whether the proportions of VOT duration in relation to word duration (=dependent variable termed "VOT proportion") was dependent on a number of independent variables (see below), a Linear Mixed Model (Baayen 2008) with Poisson error structure was used. The following independent variables were used: (a) interaction term of age and education (age ${ }^{\star}$ education; i. e., age: $<40$ years, $>50$ years; education: primary, secondary or tertiary education as highest degree), (b) gender (i. e., male, female) of participants, (c) elicitation mode of words (i. e., picture naming, reading), (d) vowel type following the plosives (high $=\langle i, \ddot{u}, u)$, mid $=\langle\mathrm{e}, \ddot{\mathrm{o}}, \mathrm{o}\rangle$, low $=\langle\mathrm{a}\rangle$ ), and (e) plosive type (i.e., $\langle\mathrm{b}, \mathrm{p}, \mathrm{d}, \mathrm{t}, \mathrm{g}, \mathrm{k}\rangle)$. The intercepts for "subject" were treated as random effects. In addition, further tests were conducted with the merge indices of the three plosive types (see above) as the dependent variables and (a) age ${ }^{\star}$ education, (b) gender, and (c) place of articulation as the independent variables to investigate in detail the degree of plosive merging/splitting in the two generations. Again, "subject" was specified as random effect.

As an overall test of the effect of the test variables, the full models were compared with respective null models lacking the fixed effects (but being otherwise identical to the full models) using a likelihood ratio test (Dobson 2002; Forstmeier and Schielzeth 2011). The significance of individual fixed effects was tested by comparing the full model with a respective reduced model lacking the effect to be tested. Collinearity (Field 2005; Quinn and Keough 2002) did not appear to be an issue (maximum generalized variance inflation factors ranged from 1.1 to 2.0; see Fox and Monette 1992). Visual inspection of residual plots did not reveal any obvious deviations from homoscedasticity or normality. The models were implemented in $\mathrm{R}$ (version 3.1.2; $\mathrm{R}$ Core Team) using the function lmer of the package lme4 (Bates et al. 2014). The sample size was 1948 words of which 544 contained bilabial plosives (288 lenis, 256 fortis), 432 contained alveolar plosives (176 lenis, 256 fortis), and 672 contained velar plosives (224 lenis, 448 fortis). 
Table 4: Mean proportion of voice onset time (percentage in relation to overall word duration) according to age group, plosive type, and vowel which followed the plosives. High vowels included $\langle i, u ̈, u\rangle$, mid vowels included $\langle e, o ̈, 0\rangle$ and low vowels included $\langle a\rangle$.

\begin{tabular}{|c|c|c|}
\hline Plosive type, vowel type & $\begin{array}{r}\text { Generation } 1 \\
\text { (born 1950's/60's) }\end{array}$ & $\begin{array}{r}\text { Generation } 2 \\
\text { (born: 1980's/90's) }\end{array}$ \\
\hline Bilabial, lenis: b - low vowels & $3.4 \pm 2.6$ & $1.1 \pm 1.4$ \\
\hline Bilabial, lenis: $b$ - mid vowels & $1.9 \pm 1.8$ & $0.4 \pm 0.9$ \\
\hline Bilabial, lenis: b - high vowels & $4.6 \pm 3.1$ & $1.9 \pm 2.6$ \\
\hline Bilabial, fortis: $p$ - low vowels & $4.4 \pm 3.5$ & $9.2 \pm 5.6$ \\
\hline Bilabial, fortis: $p$ - mid vowels & $5.6 \pm 4.7$ & $10 \pm 3.9$ \\
\hline Bilabial, fortis: $p$ - high vowels & $6.8 \pm 5.2$ & $10.9 \pm 6.4$ \\
\hline Alveolar, lenis: $\mathrm{d}$ - low vowels & $3.1 \pm 2.7$ & $2.3 \pm 1.7$ \\
\hline Alveolar, lenis: $\mathrm{d}$ - mid vowels & $3.4 \pm 1.7$ & $2.2 \pm 1.8$ \\
\hline Alveolar, fortis: $\mathrm{t}$ - low vowels & $7.6 \pm 4.3$ & $12.3 \pm 6.1$ \\
\hline Alveolar, fortis: $\mathrm{t}$ - mid vowels & $14.5 \pm 9$ & $18.8 \pm 8.9$ \\
\hline Alveolar, fortis: $\mathrm{t}$ - high vowels & $11.8 \pm 8.7$ & $21.2 \pm 9.4$ \\
\hline Velar, lenis: g - low vowels & $6.5 \pm 3.5$ & $3.8 \pm 3.9$ \\
\hline Velar, lenis: $\mathrm{g}$ - mid vowels & $7.3 \pm 4.2$ & $4.4 \pm 5.1$ \\
\hline Velar, lenis: $\mathrm{g}$ - high vowels & $5 \pm 4.8$ & $3.5 \pm 5.6$ \\
\hline Velar, fortis: k - low vowels & $7.8 \pm 4.4$ & $11 \pm 4.2$ \\
\hline Velar, fortis: k- mid vowels & $10.4 \pm 7.7$ & $16.7 \pm 5.8$ \\
\hline Velar, fortis: $\mathrm{k}$ - high vowels & $13.8 \pm 7.3$ & $17.6 \pm 5.9$ \\
\hline
\end{tabular}

\section{Results}

The analysis of VOT proportions across the two generations of Austrian speakers showed that plosive type (full-null model comparison: $\chi^{2}(5)=947.2, p<0.001$ ) as well as vowel type $\left(\chi^{2}(2)=121.87, p<0.001\right)$ had highly significant influences on VOT proportions (see Table 4 for details). VOT increased from lenis to fortis and - due to the prolongation of the articulatory tract - from bilabial to the more posterior articulatory positions alveolar and velar (see also Cho and Ladefoged 1999; estimate $=\mathrm{b} \rightarrow \mathrm{p}: 6 \pm 0.5, \mathrm{~b} \rightarrow \mathrm{d}: 0.8 \pm 0.6, \mathrm{~b} \rightarrow \mathrm{t}: 13.1 \pm 0.5, \mathrm{~b} \rightarrow \mathrm{g}: 2.2 \pm$ $0.5, \mathrm{~b} \rightarrow \mathrm{k}: 11.7 \pm 0.4)$. VOT proportions were generally longer before high vowels than before mid or low vowels in both generations (estimate $=$ high $\rightarrow$ mid: $-3.8 \pm$ 0.4, high $\rightarrow$ low: $-5.1 \pm 0.5$ ), which is consistent with previous reports on Austrian German (Grassegger 1996; Moosmüller and Ringen 2004).

Furthermore, the proportions of VOT durations were shown to be influenced by the interaction of age ${ }^{\star}$ education $\left(\chi^{2}(5)=24, p<0.001\right)$ but not by gender of the speakers $\left(\chi^{2}(1)=0.12, p=0.73\right)$. Results indicated that the VOT proportions were 


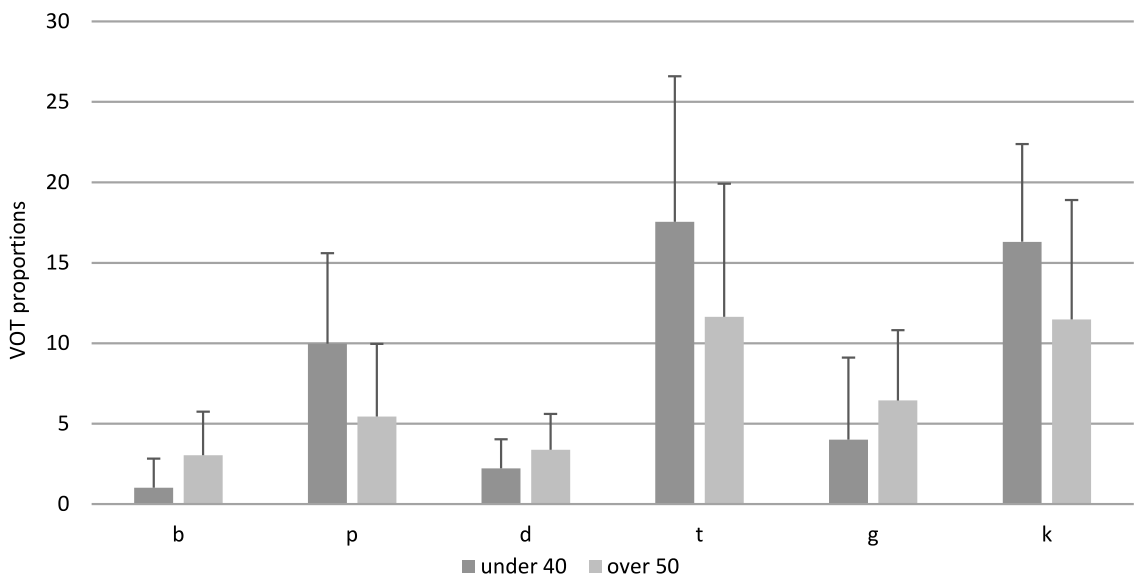

Figure 2: VOT proportions (percentage of lenis VOT in relation to fortis VOT) across plosive types and generations. The distance between lenis-fortis plosive pairs is greater in younger speakers due to shortening of VOT in lenis and lengthening it in fortis plosives.

longer in younger speakers with higher educational degrees (young + secondary education: estimate $=1.3 \pm 1.4$, young + tertiary education: estimate $=0.1 \pm 1.1$ ) Figure 2 illustrates the differences per plosive type and generation.

Elicitation mode also had a significant impact on VOT proportions $\left(\chi^{2}(1)=3.9\right.$, $p=0.05$, estimate $=0.95 \pm 0.5)$ which were longer in the picture naming $(9.1 \pm 8.1)$ than in the reading tasks $(8.1 \pm 7.6)$.

The merge index - measuring the distance between lenis and fortis plosive pairs - was not affected by speaker gender $\left(\chi^{2}(1)=0.03, p=0.9\right)$, but by the interaction of age and education $\left(\chi^{2}(1)=36.9, p<0.001,<40+\right.$ secondary education: estimate $=3.4 \pm 16.3$, <40+tertiary education: estimate $=14 \pm 12$ ). In addition, place of articulation had an important effect on the merge index $\left(\chi^{2}(2)=20, p<0.001\right.$, estimate $=$ alveolar $>$ bilabial: $22.2 \pm 5.6$, alveolar $>$ velar: $20.3 \pm 5.6$ ). Speakers over 50 years with lower education (primary and secondary schooling) showed significant overlap between lenis and fortis variants of their bilabial plosives (merge indices: $>50$ generation: $73 \pm 41,<40$ generation: 11.5 \pm 10.2 ). Concerning the alveolar plosives, the merger in the $>50$-generation was less pronounced, with the highest merge index around $27( \pm 11)$, but again the $<40$-generation showed a lower merge index (13.1 \pm 4.2$)$. In the velar plosives, the $>50$-generation also showed more pronounced merging of lenis and fortis constrasts (merge index: $57 \pm 17.8$ ), while the $<40$-generation was well below that (24 \pm 7.8 ; see Figure 3$)$. 
bilabial plosives

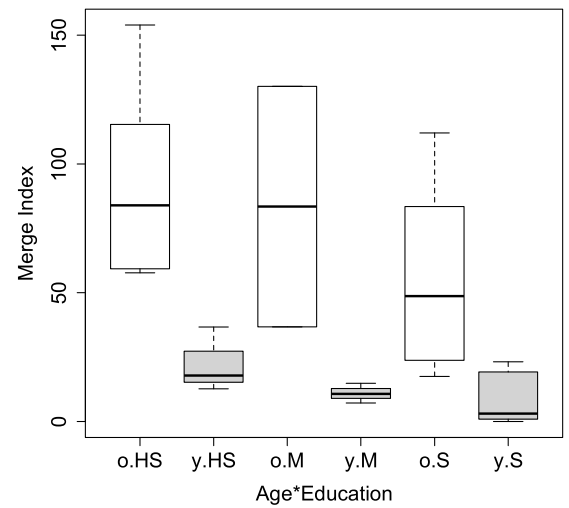

alveolar plosives

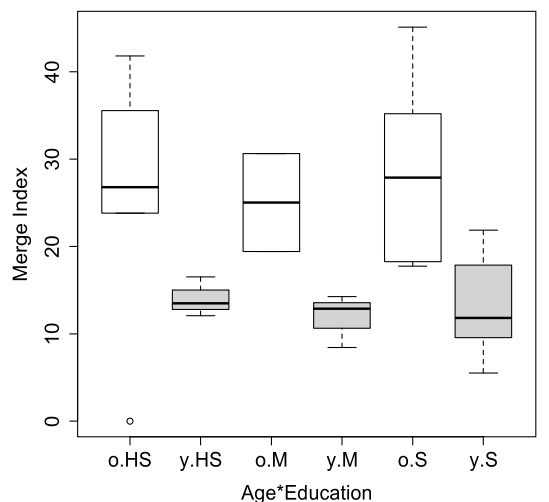

velar plosives

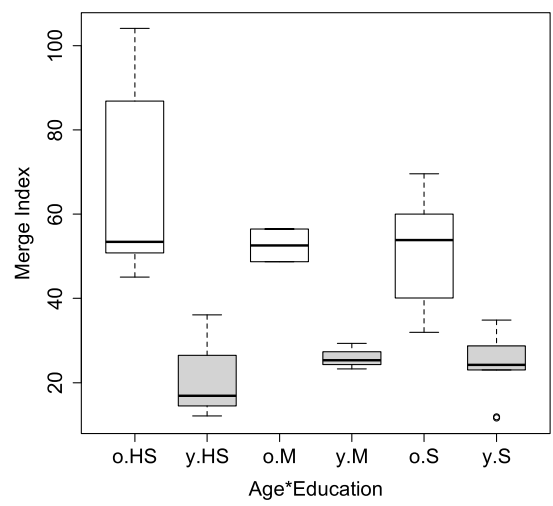

Figure 3: Merge indices for bilabial, alveolar and velar plosives according to age*education interaction term ( $y=$ young, i. e., under 40 years in gray; 0 = old, i. e., over 50 years in white; HS = "Hauptschule"/primary education, $M$ = "Matura"/secondary education, $\mathrm{S}$ = "Studium"/tertiary education).

Table 5 shows the actual VOT values in comparison to VOT proportions as measured in milli-seconds for the six plosive types across the two generations. As can be seen, in the bilabial plosives the $<40$-generation showed a decrease in the VOT proportions of the lenis variant by a third and an increase in the fortis variant by 1.8 times on average. In the alveolar plosives, younger speakers showed a decrease in the VOT proportion of the lenis variant and an increase in the VOT proportion of the fortis variant both by times 1.5. In the velar plosives, the VOT proportion of the lenis variant was decreased times 0.7 , while in the fortis variant it was increased times 0.1 . 


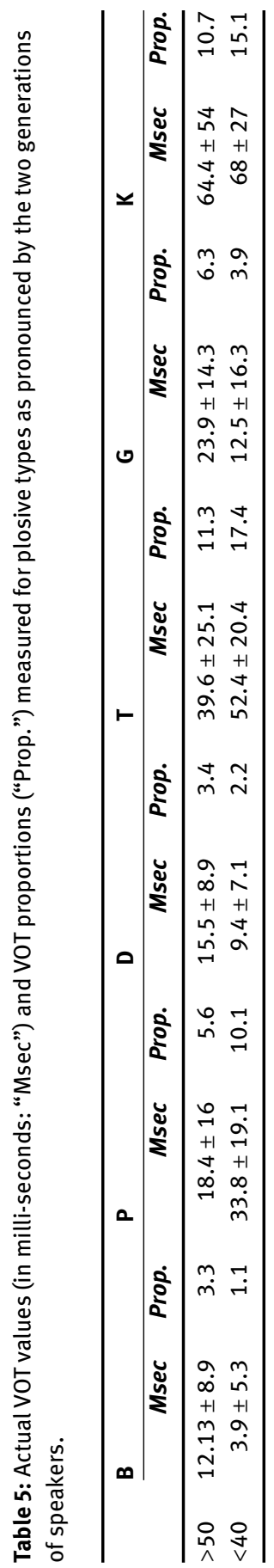




\section{Discussion}

The present study investigated the development of voice onset time in an ongoing phonetic split of word-initial plosives in Austrian German. As opposed to consonantal mergers, descriptions of consonantal splits are rare in the phonetic literature (see, e.g., Hall 2013) and studies investigating the acoustics of plosive splits can contribute to our understanding of sound change.

The present results show that speakers born at the end of the 20th century (in 1980's and 90's) have developed more phonetic distance between lenis and fortis plosive pairs in terms of VOT duration as compared to the generation of speakers born in the middle of the 20th century (1950's and 60's). The older generation may have experienced a near-merger, with phonemically distinct plosives retained in their linguistic system, but moved toward phonetic merging by approximating the VOTs of their fortis and lenis plosive pairs. This near-merger may have been reversed (or is in the process of reversal) in the younger generation of Austrians. Speech of younger speakers is characterized by shorter lenis VOT and longer fortis VOT in relation to speakers over 50 years of age. The $>50$-generation displays greater merging tendencies across all places of articulation which is particularly pronounced in the bilabial plosives. The plosive split in younger speakers' speech has widened the distances between VOT of lenis and fortis pairs in bilabial, alveolar, and velar plosives.

Two mechanisms play a role here: lenis-shortening and fortis-lengthening. Even though the present data is limited in terms of what it can say about the origin of the split, there are some tentative insights that can be gained regarding the two mechanisms and which one of the two possibly leads the split. Concerning the bilabial plosives, it seems that lenis-shortening is more pronounced than fortis-lengthening, whereas in the alveolar pair, the gap between lenis and fortis seems to widen due to lenis becoming shorter at the same rate as fortis is becoming longer. In velars, only limited lenis-shortening and no fortis-lengthening seem to take place. The most consequential change has certainly occurred in lenis-shortening of the bilabial /b/, followed by bilabial fortis-lengthening in $/ \mathrm{p} /$. These data support results by Moosmüller and Ringen (2004) who found more variation in bilabial and alveolar plosives than in velars in Austrian speakers from Vienna and thus suggested that changes may be ongoing in pronuncation patterns of the more anterior plosives. Moosmüller and Ringen (2004) described a trend for neutralization of fortis-lenis contrasts in terms of spread glottis involvement at the phonetic level (while maintaining contrast at the phonemic level), which was most pronounced in bilabial and alveolar places of articulation. The authors suggested that Standard Austrian could possibly develop a merger of fortis-lenis contrasts in bilabial and alveolar plosives by neutralizing the [ \pm spread glottis] 
feature. The results of the present study seem to indicate that Austrians under 40 years of age have undergone a process of increasing phonetic contrasts between fortis and lenis plosive pairs. In particular the lengthening of fortis VOT indicates that the spread glottis feature is becoming more pronounced (similar to North and Middle Standard German), rather than less, in younger Austrian speakers.

Austrian pronunciation is sometimes defined as non-aspirational in the literature (i. e., no long lag VOTs over 40 msec; Siebs 1969; Hildenbrandt et al. 2013). However, Moosmüller (2011) documents VOT values between 40 and $60 \mathrm{msec}$ for fortis plosives and in the present study, aspiration was also commonly measured (in alveolar and velar positions) in both generation of speakers. It seems that aspiration has been introduced into Standard Austrian German and now constitutes a feature of contemporary pronunciation (Moosmüller et al. 2015). The fact that the bilabial split that was observed by the present study seems to primarily result from lenis-shortening, rather than fortis-aspiration, could be related to aerodynamic or articulatory aspects of plosive production.

Previous studies on the influence of speaker age on VOT duration in English, French and Hungarian have yielded mixed results. Some studies found increased variability (Petrosino et al. 1993; Ryalls et al. 1997), while others found shorter (Benjamin 1982) or longer VOTs (Bóna 2014) in older speakers. Some studies found differences in relation to contextual occurrence of the plosives or places of articulation or no age-related differences at all (Bóna 2014; Neiman et al. 1983; Torre and Barlow 2009). The results of the present study are somewhat problematic to reconcile with the existing literature. Even though they show shorter VOT values in older speakers, similar to Benjamin (1982), short lag VOT has always been a characteristic feature of Austrian German. It is thus reasonable to assume that short VOTs in speakers over 50 years could be indicative of a more traditional Austrian pronunciation. In addition, older speakers in the present study were between 50 and 68 years, which is younger than the older age groups in previous studies (which were between 68 and 90 years), making physiological causes less likely to have an impact. More research is clearly needed to determine the degree of age-related influences on VOT in Austrian speakers.

The occurrence of splits and mergers in languages raises the general question of why sound change happens in the first place. Developments in Austrian German cannot be considered separately from the larger German language family and in particular the majority language in German-speaking Europe, Standard German as spoken in Germany (in particular in the Middle and North). Long lag VOT has existed in North and Middle Standard German throughout the 20th century and could have had a certain phonetic pull-effect within the Germanspeaking area. Phonetic mergers taking place within a sub-variety of a specific language, may never reach full completion when phonetic contrasts are retained 
in the majority language (compare vowel split in Shanghai Chinese: Yao and Chang 2016). In such a case, the merger may progress far but stay reversible (i. e., a near-merger). Even though the question of reversibility of mergers has not been conclusively resolved (Labov et al. 1991), it seems that in Austrian German a previous (at least near-) merger of plosive VOT is being reversed in the younger generations. The linguistic behavior of the younger generation can thus be interpreted as a strategy to avoid near-mergers. This has an interesting parallel to the discussion of the presumed Middle High German and Northern High German cases of final devoicing that do not seem to be complete neutralizations but merely nearmergers (Mihm 2007). If the reason for this phonetic differentiation in word-initial plosives as measured by the present study is indeed the influence from Northern and Middle Standard German, we can observe two different scenarios of a clear phonetic marking of a phonological contrast in German. Northern and Middle Standard German is characterized by a rather strong fortis-lenis distinction and has enhanced the category [+fortis] to [+aspirated]. Austrian Standard German achieves the same goal of an increase of fortis-lenis distinction with a focus on lenition of the lenis plosives. This means there are two trajectories of phonetic change for one (idential) phonological goal.

North and Middle Standard German is ubiquitous in Austria, so that the younger generation of Austrian speakers are well familiar with the particular pronunciation patterns (Sedlaczek 2004). Within German-speaking Europe, North and Middle Standard German is regarded as the model of the German language, and even many educated Austrians regard the Austrian variety as "less correct" than North and Middle Standard German (Fink et al. 2017). This indicates a certain orientation toward North and Middle Standard German in terms of pronunciation, a fact that can explain why younger generations of Austrian would be more inclined to emulate North and Middle Standard German pronunciation. In Austria, an increasing number of younger speakers seem to accommodate their speech patterns toward Northern Standard Germany (Muhr 1995, 2003), a trend that can also be seen in Swiss German (Hove 2002). Muhr (2003) details language contact between Northern/Middle Standard German and Austrian German and ensuing accelerated language shift in Austria made possible by the introduction of German television broadcasting in Austria beginning in the early 1980's. His study focuses on lexical features but it is not unreasonable to assume that phonetic features also cross over into Austrian German, such as the plosive split that has been described by the present study. While there seems to be no evidence that younger Austrians use Austrian dialects to a lesser degree - a fact that could well explain shifting plosive pronunciations - they certainly show a tendency to incorporate more North and Middle Standard German words into their youth language (Ziegler 2018). The side-effect of this loanword import could be a carry-over 
effect of pronunciation features which then spread from the loanwords to other words within the system. As a matter of fact, a recent investigation of the so-called "Beeren-Bären merger" in German has revealed that a reversal of that merger is ongoing in Austria at the moment and that the causes seem an accommodation toward the Northern German Standard variety where the two front vowels are not merged (Sloos 2018). Similar to the present case of plosive near-merger reversal, the existence of distinct graphemes may have inhibited a full merger in the older generation, with the younger generation recovering from this near-merger at the moment. There seems to be a general phonetic/phonological tendency within the pluricentric German-speaking area to orient toward the Northern German variety. This includes the replacement of the Southern trilled / $r /$ with the more Northern uvular /R/, a slow but steady change of Austrian unrounded front vowels in the direction of Northern German vowels (Sloos and Neijmeijer 2016), and the voiceless alveolar sibilant /s/ becoming voiced /z/ before a vowel as in the word Sonne 'sun' in Swiss German (Hove 2002). In sum, there is sufficient evidence that indicates that the German variety as spoken in Germany (in particular in the Middle and Northern regions) heavily influences Austrian German and the results of the present study likely fit this general pattern.

The sample of the present study was drawn from a region of Austria (Upper Austria) that borders with Germany and approximation of the North and Middle Standard German accent may be more prevalent there than in central or Eastern regions of Austria. Considering the dialect continuum across the AustrianBavarian border, it makes sense to propose that a similar intergenerational difference in plosive pronunciation could be found in neighboring Bavarian regions, a topic that has not been investigated to date. Furthermore, it is unclear at the moment whether this near-merger recovery occurs in other Austrian regions as well, a topic that remains to be investigated by future studies. Near-mergers can only be definitively established by investigating a possible perceptual difference that speakers may have retained of a sound contrast. This was, however, not within the scope of the present study which was designed as an exploratory first study of a previously unknown phenomenon in Austrian German. Future studies should test perception and production in speakers of merged and unmerged plosive variants. As has been suggested by Moosmüller and Ringen (2004) in their study of Austrian plosives, bilabials have undergone the most significant changes in recent history and thus studying them in closer detail may reveal interesting perspectives. Another fact that could help shed light on the spread of the plosive sound change would be to investigate mother-infant interactions to see whether mothers of the younger generation convey the split in their infant-directed speech (see, e. g., Salmons et al. 2012). Finally, a lack of comparable studies on North and Middle Standard German makes it difficult to interpret developments in Austrian Ger- 
man and it would be useful to investigate plosive pronunciation in North and Middle Standard German in speakers of different generations to determine whether current plosive changes are a larger-scale phenomenon taking place in German. A better understanding of VOT developments within the entire German-speaking area are crucial when trying to make sense of particular phenomena occurring within a linguistic variety.

\section{Concluding remarks}

Austrian German plosive pronunciation in word-initial position has undergone changes in the younger generation born toward the end of the 20th century as compared to the generation born in the middle of the 20th century. Younger speakers show a split in word-initial plosives, where fortis and lenis pairs of a plosive type are characterized by greater VOT distance, i. e. shorter lag lenis and longer lag fortis. Speakers over 50 years of age show more pronounced tendencies to merge fortis-lenis contrasts, with the bilabial plosives reaching almost $80 \%$ of VOT overlap. These merging tendencies were dissolved by the younger generation across all places of articulation (however to varying degrees) and speech of younger Austrians seems to approximate North and Middle Standard German pronunciation. At present it is not predictable whether this particular sound change will prevail in Austrian German or potentially develop further in future generations (see Zellou and Tamminga 2014, for reversals of sound changes).

Acknowledgment: This work was supported by the 'Research Resettlement Fund for New Faculty' and the 'Overhead Fund 2017' of the College of Education of Seoul National University. I would like to thank Jong-seung Sun, Hyuksun Kwon, Hannah Kim, Christian Blum, and Magdalena Pelayo-van Buuren for their help during various stages of data collection.

\section{References}

Abramson, Arthur S. \& Douglas H. Whalen. 2017. Voice onset time (VOT) at 50: Theoretical and practical issues in measuring voicing distinctions. Journal of Phonetics 63, 75-86.

Ammon, Ulrich. 2003. Dialektschwund, Dialekt-Standard-Kontimuum, Diglossie: Drei Typen des Verhältnisses Dialekt-Standardvarietät im deutschen Sprachgebiet. In: Jannis Androutsopoulos \& Evelyn Ziegler (eds.), Standardfragen: Soziolinguistische Perspektiven auf Sprachgeschichte, Sprachkontakt und Sprachvariation, 163-171. Frankfurt am Main: Peter Lang. 
Baayen, Harald. 2008. Analyzing linguistic data. Cambridge: Cambridge University Press. Bailey, Guy. 2002. Real and apparent time. In: J. K. Chambers, Peter Trudgill \& Natalie Schilling-Estes (eds.), The handbook of language variation and change, 312-332. Oxford: Blackwell.

Barry, William \& Bistra Andreeva. 2001. Cross-language similarities and differences in spontaneous speech patterns. Journal of the International Phonetic Association 31(1), 51-66.

Bates, Douglas, Martin Maechler, Benjamin Bolker \& Steven Walker. 2014. Linear mixed-effects models using Eigen and S4. $R$ Package version 1.1.-7.

Beckmann, Jill, Michael Jessen \& Catherine Ringen. 2013. Empirical evidence for laryngeal features: Aspirating vs. true voice languages. Journal of Linguistics 49(2), 259-284.

Benjamin, Barbaranne J.. 1982. Phonological performance in gerontological speech. Journal of Psycholinguistic Research 11(2), 159-167.

Boersma, Paul \& David Weenink. 2007. Praat: Doing phonetics by computer [Computer program]. Version 4.5.25, http://www.Praat.org.

Bóna, Judit. 2014. Voice onset time and speakers' age: Data from Hungarian. Clinical Linguistics and Phonetics 28(5), 366-372.

Cho, Taehong \& Peter Ladefoged. 1999. Variation and universals in VOT: Evidence from 18 languages. Journal of Phonetics 27(2), 207-229.

Coetzee, Andries W., Patrice Speeter Beddor, Kirby Shedden, Will Styler \& Daan Wissing. 2018. Plosive voicing in Afrikaans: Differential cue weighting and tonogenesis. Journal of Phonetics 66, 185-216.

Dobson, Anette J. 2002. An introduction to generalized linear models. Boca Raton, FL: Chapman \& Hall.

Ender, Andrea \& Irmtraud Kaiser. 2011. A cognitive approach to sociolinguistic variation in Austria: Diglossia or dialect-standard-continuum in speakers' awareness and usage. Paper presented at the 34th LAUD Symposium: Cognitive Sociolinguistics - Language Variation in its Structural, Conceptual and Cultural Dimension. Landau, Germany.

Field, Andy. 2005. Discovering statistics using SPSS. London: Sage Publications.

Fink, Ilona E., Jutta Ransmayr \& Rudolf de Cillia. 2017. "Also grammatisch würd ich fast sagen, dass die Österreicher inkorrekt sind, aber sonst eigentlich gar nicht." Wahrnehmungen von und Einstellungen gegenüber Varietäten des Deutschen bei österreichischen LehrerInnen und SchülerInnen. ÖDaF-Mitteilungen: Brückenbögen und Tragwerksstrukturen in der DaF/DaZ-Landschaft in Österreich 33, 79-96.

Forstmeier, Wolfgang \& Holger Schielzeth. 2011. Cryptic multiple hypotheses testing in linear models: Overestimated effect sizes and the winner's curse. Behavioral Ecology and Sociobiology 65(1), 47-55.

Fox, John \& Georg Monette. 1992. Generalized collinearity diagnostics. Journal of the American Statistical Association 87(417), 178-183.

Grassegger, Hans. 1996. Koartikulatorische Einflüsse auf die Produktion von Anlautplosiven bei österreichischen (steirischen) Sprechern. In Angelika Braun (ed.), Untersuchungen zu Stimme und Sprache - Papers on speech and voice, 19-32. Stuttgart: Franz Steiner.

Hall, Kathleen C. 2013. Documenting phonological change: A comparison of two Japanese phonemic splits. In S. Luo (ed.), Proceedings of the 2013 annual conference of the Canadian Linguistic Association, 1-15. Toronto: Canadian Linguistic Association.

Hamann, Silke \& Klaas Seinhorst. 2016. Prevoicing in German plosives: Implications for phonological representations. Paper presented at the Thirteenth Old World Conference 
in Phonology. Budapest, Hungary.

Hardcastle, William J. 1973. Some observations of the tense-lax distinction in initial stops in Korean. Journal of Phonetics 1, 263-271.

Hickey, Raymond. 2000. Salience, stigma and standard. In Laura Wright (ed.), The development of standard English 1300-1800: Theories, descriptions, conflicts, 57-72. Cambridge: Cambridge University Press.

Hickey, Raymond. 2004. Mergers, near-mergers and phonological interpretations. In: Christian J. Kay, Carol Hough \& Irené Wotherspoon (eds.), New perspectives on English historical linguistics, 125-137. Amsterdam: Benjamins.

Hickey, Raymond. 2012. Internally and externally motivated language change. In: Juan M. Hernández-Compoy \& Juan C. Conde-Silvestre (eds.), The handbook of historical sociolinguistics, 401-421. Malden, MA: Wiley-Blackwell.

Hildenbrandt, Tina, Sylvia Moosmüller \& Friedrich Neubarth. 2013. Orthographic encoding of the Viennese dialect for machine translation. In: Zymunt Vetulani \& Hans Uszkoreit (eds.), Proceedings of the 6th language \& technology conference (LTC 2013), 399-403. Poznan, Poland.

Honeybone, Patrick. 2005. Diachronic evidence in segmental phonology: The case of obstruent laryngeal specifications. In: Marc van Oostendorp, \& Jeroen van de Weijer (eds.), The internal organization of phonological segments, 317-352. Berlin \& New York: de Gruyter Mouton.

Hove, Ingrid. 2002. Die Aussprache der Standardsprache in der deutschen Schweiz. Tübingen: Niemeyer.

Iverson, Gregory \& Joseph C. Salmons. 1999. Glottal spreading bias in Germanic. Linguistische Berichte 178, 135-151.

Jessen, Michael. 1998. Phonetics and phonology of tense and lax obstruents in German. Amsterdam: Benjamins.

Jessen, Michael \& Catherine Ringen. 2002. Laryngeal features in German. Phonology 19, 189-218.

Kang, Yoonjung. 2014. Voice onset time merger and development of tonal contrasts in Seoul Korean stops: A corpus study. Journal of Phonetics 45, 76-90.

Kanwal, Jasmeen \& Amanda Ritchart. 2015. An experimental investigation of tonogenesis in Punjabi. In: The Scottish Consortium for ICPhS 2015, Proceedings of the 18th international congress of phonetic sciences. Glasgow: The University of Glasgow. https://www. internationalphoneticassociation.org/icphs-proceedings/ICPhS2015/Papers/ICPHS0929. pdf.

Kohler, Klaus. 1977. Einführung in die Phonetik des Deutschen. Berlin: Schmidt.

Kohler, Klaus. 1984. Phonetic explanation in phonology: The feature fortis/lenis. Phonetica 41, 150-174.

Kuang, Jianjing \& Mira Oh. 2011. Does merger happen in the three-way contrast of Korean stops. The Journal of the Acoustical Society of America 129(4). DOI: 10.1121/1.3588058.

Labov, William. 1963. The social motivation of a sound change. Word 19, 273-309.

Labov, William. 1966. The social stratification of English in New York City. Washington, DC: Center for Applied Linguistics Press.

Labov, William. 1987. The overestimation of functionalism. In: Dirven, R. \& Fried, V. (eds.), Functionalism in linguistics, 311-332. Amsterdam: Benjamins.

Labov, William. 1994. Principles of linguistic change: Volume 1: Internal factors. Oxford: Blackwell. 
Labov, William, Mark Karen \& Corey Miller. 1991. Near-mergers and the suspension of of phonemic contrast. Language Variation and Change 3(1), 33-74.

Ladefoged, Peter \& Ian Maddieson. 1996. The sounds of the world's languages. Oxford: Blackwell.

Lisker, Leigh \& Arthur S. Abramson. 1964. Cross-language study of voicing in initial stops: Acoustical measurements. Word 20(3), 384-422.

Liu, Jinyuan, Wan Tang, Guanqin Chen, Yin Lu, Changyong Feng \& Xin M. Tu. 2016. Correlation and agreement: Overview and clarification of competing concepts and measures. Shanghai Archives of Psychiatry 28(2), 115-120.

MacLeod, Bethany. 2012. The effect of perceptual salience on phonetic accommodation in cross-dialectal conversation in Spanish. PhD dissertation, University of Toronto, Toronto, Canada. https://tspace.library.utoronto.ca/handle/1807/34794.

Malécot, André. 1970. The lenis-fortis opposition: Its physiological parameters. The Journal of the Acoustical Society of America 47, 1588-1592.

Martin, Alexander, Mareike van Heugten, René Kager \& Sharon Peperkamp. 2016. Phonological emergence in Dutch: Relating perception and production in contact-induced change. Paper presented at the Satellite Workshop "Perspectives on Marginal Contrasts" of LabPhon 15. Ithaca, NY.

Mihm, Ahrend. 2007. Theorien der Auslautverhältnis im Spannungsfeld zwischen Normsetzung und Sprachwirklichkeit. Deutsche Sprache 2, 95-118.

Milroy, James \& Lesley Milroy. 1999. Authority in language. London: Routledge.

Moosmüller, Sylvia. 1987. Soziophonologische Variation in gegenwärtigen Wiener Deutsch: Eine empirische Untersuchung. Stuttgart: Franz Steiner.

Moosmüller, Sylvia. 2011. Aussprachevarianten im Österreichischen Standarddeutsch. In: Bose, I. \& Neuber, B. (eds.), Interpersonelle Kommunikation: Analyse und Optimierung, 39-46. Frankfurt am Main: Peter Lang.

Moosmüller, Sylvia \& Catherine Ringen. 2004. Voice and aspiration in Austrian German plosives. Folia Linguistica 38, 43-62.

Moosmüller, Sylvia, Carolin Schmid \& Julia Brandstätter. 2015. Standard Austrian German. Journal of the International Phonetic Association 45(3), 339-348.

Morris, Richard J., Mary M. Gorham-Rowan \& Kaileen D. Herring. 2009. Voice onset time in women as a function of oral contraceptive use. Journal of Voice 23(1), 114-118.

Muhr, Rudolf. 1995. Zur Sprachsituation in Österreich und zum Begriff "Standardsprache" in plurizentrischen Sprachen: Sprache und Identität in Österreich. In: Rudolf Muhr, Richard Schrodt \& Peter Wiesinger (eds.), Österreichisches Deutsch: Linguistische, sozialpsychologische und sprachpolitische Aspekte einer nationalen Variante des Deutschen, 75-110. Wien: Hölder, Pichler, Tempsky.

Muhr, Rudolf. 2003. Language change via satellite: The influence of German television broadcasting on Austrian German. Journal of Historical Pragmatics 4, 103-127.

Neiman, Gary S., Richard J. Klich \& Elaine M. Shuey. 1983. Voice onset time in young and 70-year-old women. Journal of Speech, Language, and Hearing Research 26(1), 118-123.

Nelson, Noah R. \& Andrew Wedel. 2017. The phonetic specificity of competition: Contrastive hyperarticulation of voice onset time in conversational English. Journal of Phonetics 64, 51-70.

Neubarth, Friedrich, Michael Pucher \& Christian Kranzler. 2008. Modeling Austian dialect varieties for TTS. In: INTERSPEECH-2008, 1877-1880.

Petrosino, Linda, Roger D. Colcord, Karen B. Kurcz \& Robert J. Yonker. 1993. Voice onset time of 
velar stop productions in age speakers. Perceptual and Motor Skills 76(1), 83-88.

Petrova, Olga, Rosemarie Plapp, Catherine Ringen \& Szilárd Szentgyörgyi. 2006. Voice and aspiration: Evidence from Russian, Hungarian, German, Swedish, and Turkish. The Linguistic Review 23(1), 1-35.

Piercy, Caroline. 2011. One /a/ or two? Observing a phonemic split in progress in the Southwest of England. University of Pennsylvania Working Papers in Linguistics 17(2), article 18.

Pröll, S. \& Kleiner, S. 2016. Unterschiede bei Dialektübersetzungen in Abhängigkeit von schriftlichen und mündlichen Stimuli. Zeitschrift für Dialektologie und Linguistik 83, 293-314.

Quinn, Gerry P. \& Micheal J. Keough. 2002. Experimental designs and data analysis for biologists. Cambridge: Cambridge University Press.

Ridouane, Rachid, Susanne Fuchs \& Phil Hoole. 2006. Laryngeal adjustments in the production of voiceless obstruent clusters in Berber. In: Jonathan Harrington \& Marija Tabain (eds.), Speech production: Models, phonetic processes and techniques, 249-267. Sydney: Psychology Press.

Ryalls, Jack, Annie Cliche, Julie Fortier-Blanc, Isabelle Coulombe \& Annie Prud'Hommeaux. 1997. Voice-onset time in younger and older French-speaking Canadians. Clinical Linguistics and Phonetics 11(3), 205-212.

Salmons, Joseph C., Robert A. Fox \& Ewa Jacewicz. 2012. Prosodic skewing of input and the initiation of cross-generational sound change. In: Maria-Josep Solé \& Daniel Recasens (eds.), The initiation of sound change: Perception, production, and social factors, 167-184. Amsterdam: Benjamins.

Sankoff, Gillian \& Hélène Blondeau. 2007. Language change across the lifespan: /r/ in Montreal French. Language 83(3), 560-588.

Sedlaczek, Robert. 2004. Das österreichische Deutsch. Wien: Ueberreuter.

Siebs, Theodor. 1969. Deutsche Aussprache: Reine und gemäßigte Hochlautung mit Aussprachewörterbuch. 19. umgearb. Aufl., hrsg. von Helmut de Boor, Hugo Moser \& Christian Winkler. Berlin: Walter de Gruyter.

Sloos, Marjoleine. 2018. Merger and reversal of the Bären and Beeren vowels: The role of salience. Studia Linguistica 72(2), 282-296.

Sloos, Marjoleine \& Mathea Neijmeijer. 2016. Ongoing dispersion of Austrian Standard German front vowels: A sociolinguistic study. Athens Journal of Philology 3(1), 7-22.

Smith, Jeremy. 2007. Sound change and the history of English. Oxford: Oxford University Press.

Tillery, Jan \& Guy Bailey. 2003. Approaches to real time in dialectology and sociolinguistics. World Englishes 22(4), 351-365.

Torre, Peter III \& Jessica A. Barlow. 2009. Age-related changes in acoustic characteristics of adult speech. Journal of Communication Disorders 42, 324-333.

Wadnerkar, Meghana B., Patricia E. Cowell \& Sandra Whiteside. 2006. Speech across the menstrual cycle: A replication and extension study. Neuroscience Letters 408(1), 21-24.

Wedel, Andrew, Abby Kaplan \& Scott Jackson. 2013. High functional load inhibits phonological contrast loss: A corpus study. Cognition 128(2), 179-186.

Whiteside, Sandra, Louisa Henry \& Rachel Dobbin. 2004. Sex differences in voice onset time: A developmental study of phonetic context effects in British English. The Journal of the Acoustical Society of America 116, 1179-1183.

Winford, Donald. 2005. Contact-induced changes: Classification and processes. Diachronica 22(2), 373-427.

Yao, Yao, \& Charles B. Chang. 2016. On the cognitive basis of contact-induced sound change: 
Vowel merger reversal in Shanghainese. Language 92(2), 433-467.

Zellou, Georgia \& Meredith Tamminga. 2014. Nasal coarticulation changes over time in Philadelphia English. Journal of Phonetics 47, 18-35.

Ziegler, Arne. 2018. Undoing youth: Dialect levelling and restandardisation in urban vernaculars in Austria. In: Arne Ziegler (ed.), Youth languages: current perspectives of international research, 49-65. Berlin \& Boston: de Gruyter.

Supplemental Material: The online version of this article offers supplementary material (https://doi.org/10.1515/zfs-2019-2006). 